\title{
O tema da subjetividade e os limites da história: uma leitura de Sartre a partir de suas influências kierkegaardianas
}

\section{The thematic of subjectivity and the limits of history: a reading of Sartre from his Kierkegaardian influences}

DOI:10.12957/ek.2018.38277

Prof. Dr. Marcio Gimenes de Paula marciogimenes@unb.br

Universidade de Brasília

O objetivo do presente artigo é avaliar, a partir de pequenos e selecionados fragmentos da obra de Sartre, a presença do tema da subjetividade e a crítica ao conceito de história tal como pensado por Kierkegaard. Para tanto, o trabalho será delimitado em três pontos: o primeiro almeja avaliar tais questões a partir de menções explícitas a Kierkegaard feitas em O Ser e o Nada e também em dois pequenos textos do pensador francês, a saber, $O$ existencialismo é um humanismo e $O$ universal singular. $\mathrm{O}$ segundo ponto do trabalho avaliará o tema da subjetividade e da crítica da história em fragmentos selecionados da obra de Kierkegaard, tais como, O Conceito de angústia, Migalhas filosóficas e o Pós-Escrito às Migalhas filosóficas. Já o problema do eu pensado por Kierkegaard - e posteriormente por Sartre - será retomado na terceira divisão do artigo e, nesse sentido, o foco principal aqui se concentrará na obra $A$ Doença para a Morte. Por fim, concluiremos o trabalho investigando qual era o Kierkegaard conhecido por Sartre, seus limites e perspectivas. 
The aim of this article is to evaluate, from small and selected fragments of Sartre's work, the presence of the thematic of subjectivity and the criticism of the concept of history as conceived by Kierkegaard. To do so, the work will be delimited in three points: the first aims to evaluate such questions from explicit references to Kierkegaard made in The Being and the Nothingness and also in two small texts of the French thinker, namely The existentialism is a humanism and The singular universal. The second point of the work will evaluate the theme of subjectivity and the critique of history in selected fragments of Kierkegaard's work, such as The Concept of Anxiety, Philosophical Fragments and the Concluding Unscientific Postscript to Philosophical Fragments. Already the problem of self thought by Kierkegaard - and later by Sartre - will be resumed in the third division of the article and, in this sense, the main focus here will focus on the work Sickness unto Death. Finally, we will conclude the work by investigating which was the Kierkegaard knew about Sartre, his limits and perspectives.

\section{KEY-WORDS Contemporary Philosophy, History, Kierkegaard, Sartre, Subjectivity.}




\section{Introdução}

Hannah Arendt aponta, com bastante propriedade e vigor, que o termo existencialista ou filosofia da existência, já nos tempos de Sartre e Camus - e em especial em contexto francês, significam pouca coisa ou quase nada. Nesse sentido, não é fortuito que em seu texto denominado $O$ existencialismo francês a autora faça uma clara referência a uma faceta pouca acadêmica desse novo tipo de pensamento ou moda filosófica, como talvez seria mais apropriado dizer. Tal tipo de nova reflexão entra agora na ordem do dia, ocorreu especialmente assim no contexto do pós-guerra. "Filósofos se tornam jornalistas, dramaturgos, romancistas. Não são docentes universitários, mas 'boêmios' que moram e vivem nos cafés" (ARENDT, 2008, 217).

Contudo, ao mesmo tempo que tal reflexão pode "vulgarizar" a filosofia, Arendt aqui enxerga uma oportunidade única:

Uma palestra sobre filosofia provoca um tumulto, centenas se aglomerando para entrar e milhares indo embora. Livro com problemas filosóficos que não pregam doutrinas baratas e não oferecem nenhuma panaceia - pelo contrário, tão difíceis que requerem uma verdadeira reflexão - vendem como romances policiais. (ARENDT, 2008, 217)

Feita tal menção - muito breve- sobre o contexto tão amplo que se insere o chamado existencialismo e, notadamente o existencialismo francês de Sartre, cabe perceber que o filósofo foi inúmeras coisas no decorrer de sua existência: pensador, literato, militante político e etc. Contudo, interessa-nos aqui, a partir do pequeno recorte que fizemos, captar um pouco mais de sua análise sobre o problema da subjetividade e da história. Para tanto, nos valeremos especialmente de sua interpretação acerca do dinamarquês Kierkegaard, considerado por muitos até os dias atuais, como uma espécie de mestre fundador do existencialismo - ou daquilo que se convencionou assim chamar. Por isso, no entender de Arendt em seu texto O que éfilosofia da existência, observamos a seguinte sentença: "A filosofia da existência moderna começa com Kierkegaard. Não existe um único filósofo existencial que não se mostre influenciado por ele" (ARENDT, 2008, 201). Com efeito, seguindo tal pista interessa-nos perceber - na medida do possível - alguns passos de Sartre nessa direção e também como ele fundamenta a partir de tal perspectiva não apenas sua ideia de subjetividade e crítica da história, mas também 
como ele constrói sua perspectiva sobre o eu e em que efetivamente ele parece se apropriar aqui da herança kierkegaardiana. Em outras palavras, como ocorre sua adesão crítica ao pensador. Segundo Reynolds, "Kierkegaard foi um dos primeiros a sublinhar a relevância filosófica de experiência como desespero e temor, precursoras da Angst heideggeriana e da angústia sartreana" (REYNOLDS, 2013, 17) e mesmo seu opositores, como o pensador católico Jolivet, é capaz de reconhecer sua importância para o pensamento, notadamente para a crise mundial ocorrida após a Segunda Guerra Mundial: "Dir-se-á que se faz muito barulho por nada. Seria, porém, um erro, porque esse homem que, como Kierkegaard, embora num sentido totalmente diverso, se dedicou a missão de inquietar os seus contemporâneos conseguiu-o muito bem e em todos os domínios" (JOLIVET, 1968, 08). Passemos, então, a primeira parte do nosso artigo.

\section{Fragmentos kierkegaardianos no pensamento de Sartre: uma análise a partir de citações de $\mathrm{O}$ Ser e o Nada e dos textos $O$ universal singular e $O$ existencialismo é um humanismo}

Como bem nos adverte Beaufret, "estudar a fundo o existencialismo de Jean-Paul Sartre exigiria que se fizesse seriamente a análise de seu livro L'Etre et le Neant" (BEAUFRET, 1976, 33). Visto que aqui não é esse nosso objetivo e que também não dispomos de tempo e espaço suficiente para tal investigação, nos limitaremos aqui a observar significativas menções a Kierkegaard em dois textos de Sartre: o primeiro é O Ser e o Nada propriamente dito e, posteriormente, avaliaremos a influência de Kierkegaard em outros dois trabalhos sartreanos: $O$ existencialismo é um humanismo e O universal singular.

O Ser e o Nada data de 1943. Trata-se, como apontado no próprio subtítulo da obra, de "um ensaio de ontologia fenomenológica". Sartre encontra-se aqui sob forte influência da filosofia de Husserl e, sem dúvida alguma, mostra haver estudado com muito afinco as teses de Hegel, do idealismo alemão, de Heidegger e chega até a psicanálise contemporânea exatamente por produzir uma crítica muito forte da metafísica clássica e de boa parte dos seus conceitos.

A primeira parte de $O$ Ser e o Nada tem o título O problema do nada. A introdução intitula-se Em busca do ser. Por sua vez, o capítulo primeiro da primeira parte se chama $A$ origem da negação. Ali, na quinta divisão do presente capítulo, denominado $A$ origem do nada, aparece a primeira menção explicita a Kierkegaard: 
Kierkegaard descrevendo a angústia da culpa, caracteriza-a como angústia frente à liberdade. Mas Heidegger, que, como se sabe, sofreu profundamente a influência de Kierkegaard, considera a angústia, ao contrário, como captação do nada. Duas descrições da angústia que não parecem contraditórias mas, ao contrário, implicam-se mutuamente”. (SARTRE, 2011, 72-73)

Aqui surge claramente o tema da angústia kierkegaardiana sendo apropriada por Sartre, isto é, a angústia é sempre uma possibilidade de escolha. Portanto, um ato ético e moral decorrente da liberdade do homem. É certo que aqui precisaríamos nos demorar um pouco mais no tema da angústia kierkegaardiana especialmente observando o que diz o seu principal tratado sobre tal temática, ou seja, $O$ Conceito de angústia, coisa que pretendemos fazer um pouco melhor na segunda parte do artigo. Assim sendo, resta notar aqui que também Heidegger sofreu a forte influência kierkegaardiana no tema da angústia e, no entender de Sartre, a angústia heideggeriana é, no fundo, tributária ao nada, coisa que Kierkegaard bem explorou no Conceito de angústia ao perceber que Adão, o primeiro homem, na verdade é tomado por uma espécie de desejo de nada, uma vez que não podia ainda ser culpado ou sequer saber o que isso significava o seu pecado e sua posterior expulsão do paraíso. Tal intepretação sartriana da angústia, situada entre a sua própria posição e a posição de Heidegger é confessadamente uma leitura de um importante intérprete da filosofia kierkegaardiana na França: Jean Wahl ${ }^{1}$. Curiosamente, Sartre não toma a posição kierkegaardiana de angústia como liberdade e a posição heideggeriana de angústia como captação do nada como excludentes, mas como complementares, o que pode ser muito significativo para pensarmos a sua própria filosofia como algo que se situou exatamente em tal linha de fronteira, a saber, entre a liberdade da escolha e o nada.

Na leitura que Sartre faz da angústia kierkegaardiana, o pensador francês elogia o pensador de Copenhague por perceber claramente que a angústia não possui relação com o medo, pois o medo é sempre relativo a algo externo a mim, ao passo que a angústia é sempre relativo a mim, aquilo que me é mais subjetivo e precioso. Por isso, no seu entender, "a vertigem é angústia na medida em

1 A referência a Jean Wahl (e seu artigo Kierkegaard et Heidegger) aparece claramente no texto de Sartre, isto é, na nota 16 da página 72 de O Ser e o Nada (edição brasileira). Para maiores informações sobre a recepção de Kierkegaard na França, recomendamos a leitura do excelente trabalho de Hélène Politis:

Politis, H. Kierkegaard en France au XXe siècle: Archéologie d'une réception, Éditions Kimé, Paris, 2005. 
que tenho medo, não de cair no precipício, mas de me jogar nele" (SARTRE, 2005, p. 73). Por isso, Sartre explora aqui a face mais concreta da angústia não como medo, mas como "medo de ter medo" (SARTRE, 2005, p. 73). Assim, aos olhos do pensador, "medo e angústia são mutuamente excludentes, já que o medo é apreensão irrefletida (irréflechie) do transcendente e angústia apreensão reflexiva de si" (SARTRE, 2005, p. 73). Contudo, também pode haver uma angústia em estado puro. Em outras palavras, aquela que não é seguida ou precedida pelo medo. Nesse sentido, Sartre fornece aqui o exemplo de alguém que, incumbido de uma importante missão, teme fracassar (SARTRE, 2005, p. 73).

A outra citação de Kierkegaard que aparece em O Ser e o Nada está localizada na segunda parte da obra intitulada O Ser-Para-Si. Mais especificamente a citação se encontra no capítulo primeiro intitulado Estrutura imediata do Para-si, no subitem terceiro denominado O Para-si e o Ser do valor. Trata-se, na verdade, de uma referência numa nota de rodapé que certamente mereceria explicações mais precisas e aprofundadas ${ }^{2}$. O assunto abordado está diretamente relacionado com o conceito hegeliano de Para-Si e aqui fica bastante claro o uso que Sartre faz da dialética do pensador alemão e de como se move com desenvoltura numa discussão típica do idealismo alemão e, ao mesmo tempo, bastante complexa. Não fortuitamente Sartre enuncia nessa nota um tipo de interpretação para aquilo que denominou como trindade hegeliana, a saber, O Em-si , O Para-si, O Em-si-Para-si. No primeiro residiria a tese, no segundo a antítese e no terceiro a síntese. Após longa digressão, o filósofo pensa que tal tipo de conceituação termina por aproximar-se muito das realidades ambíguas kierkegaardianas, o que parece provar o quanto Sartre sabia que a filosofia kierkegaardiana é de matriz hegeliana e nem pode ser compreendida sem o auxílio de tal pensador.

A última citação direta de Kierkegaard que aparece em $O$ Ser e o Nada está localizada na terceira parte da obra intitulada O Para-Outro. Mais especificamente a citação se encontra no capítulo primeiro intitulado $A$ existência do Outro, no subitem terceiro denominado Husserl, Hegel, Heidegger. Sartre fez menção explicita aqui a formula "Eu sou eu". No entender do pensador, há algo mais aqui para se compreender, isto é, na antiga concepção filosófica havia um jogo do conhecimento, ou seja existia uma relação entre o sujeito e o objeto, aquilo que Sartre preferiu chamar de "reflexo-refletidor", abrindo mão de qualquer consciência de cunho transcendente (SARTRE, 2005, 310). Assim sendo, não se trata mais aqui nem do $\mathrm{Eu}=\mathrm{Eu}$ (de Fichte) e nem do "Eu sou eu"

2 Nota 26 da tradução brasileira de O Ser e o Nada. 
(hegeliano). Certamente tal temática é muito rica, complexa e mereceria uma maior exploração tanto em Hegel, como no idealismo alemão e em Kierkegaard. Pretendemos retornar a ela no terceiro ponto do nosso artigo, quando almejamos analisar o eu kierkegaardiano em A Doença para a Morte. O que parece saltar aos olhos aqui é que Sartre toma Kierkegaard como o anti-Hegel e, nesse sentido, pode afirmar: "Aqui, como sempre, a Hegel deve se opor Kierkegaard, que representa as reinvindicações do indivíduo enquanto tal" (SARTRE, 2005, 310-311). Em outras palavras, o pensador francês abre aqui espaço para o importante conceito de indivíduo em Kierkegaard e tenta agora capturá-lo como um ser concreto que ultrapassa uma explicação tradicional dada pela relação sujeito-objeto e que tenta cunhar um tipo de universal sem qualquer concretude.

Já a obra $O$ Existencialismo é um humanismo, na verdade, foi escrita em 1946 e trata-se, na verdade, de uma palestra ministrada um ano antes em Paris e com o objetivo de divulgar a filosofia existencialista. É certo que o trabalho recebeu inúmeras críticas posteriores, inclusive do próprio autor. Contudo, nosso interesse aqui é perceber algumas das bases do que Sartre denominou como existencialismo e também notar a influência de Kierkegaard em tal movimento.

O texto possui um caráter claramente polêmico e nele se pode ver até mesmo as perguntas feitas na conferência e as respectivas respostas do pensador. De início, o filósofo deixa claro que almeja responder às criticas que são feitas ao existencialismo. Em outras palavras, quer defendê-lo das acusações de ser sórdido, burguês e subjetivo em demasia. Para tanto, sua estratégia consiste em retirar a discussão do âmbito estritamente popular e trazê-la para um âmbito de aprofundamento acadêmico.

Sartre reconhece em seu tempo a existência de um tipo de existencialismo cristão e outro ateu, por ele representado. Entretanto, avalia que o problema é bastante maior e necessitaria de um melhor aprofundamento, pois apenas dizer que a "existência precede a essência" ou partir da subjetividade não explicaria o tema em amplitude. Por isso é que não parece despropositado que três anos antes, isto é, em 1946, Sartre apresentou uma obra bastante bem desenvolvida no sentido de tal inquietação quando publicou $O$ Ser e o nada.

Uma de suas teses desenvolvidas em $O$ Existencialismo é um humanismo é que a filosofia moderna, mesmo tendo solapado estruturas importantes da antiga metafísica - e mesmo da crença em Deus - ainda afirma a tese central da essência precedendo a existência. No seu entender isso pode ser claramente averiguado em autores como Kant, Voltaire e Diderot, por exemplo. Nessa esteira é que ele defenderá o seu existencialismo ateu pois, na sua concepção, tal 
existencialismo é o único capaz de peremptoriamente afirmar que a existência precede a essência e recusar, de modo cabal e definitivo, a tradicional tese metafísica que advoga a existência de uma natureza humana.

Sartre defende que somente por meio de sua teoria pode ser mais significativo o tema das escolhas e da angústia, objeto por excelência das reflexões kierkegaardianas. Também o seu importante conceito de má-fé, ao qual não nos deteremos aqui, seria melhor compreendido no escopo de sua teoria. Por isso, o filósofo retoma aqui a significa história de Abraão tal como recontada por Kierkegaard em Temor e tremor e a angústia da situação:

É esse tipo de angústia que Kierkegaard chamava de angústia de Abraão. Todos conhecem a história: um anjo ordena a Abraão que sacrifique seu filho. Está tudo certo se foi realmente um anjo que veio e disse: tu és Abraão e sacrificarás teu filho. Porém, para começar, cada qual pode perguntar-se: será que era verdadeiramente um anjo? ou: será que sou mesmo Abraão? Que provas tenho?... Nada me designa para ser Abraão, e, sou a cada instante, obrigado a realizar atos exemplares. (SARTRE, 1987, 07-08)

No entender de Sartre, o existencialismo possui um confronto com a moral laica, pois esse almejava eliminar a ideia de Deus sem nenhum dano para a humanidade. Seguindo a célebre sentença do personagem de Dostoiévski nos Irmãos Karamazov, o pensador francês almeja tratar de uma moral que não possui mais em Deus o seu fator garantidor e, por esse motivo, parece permitir todas as coisas como sugere o escritor russo. A questão é, contudo, mais problemática, pois o que está em jogo não é o fim da moral, mas a constituição de uma outra moral sem Deus, onde o homem está, tal como pensava Sartre, condenado a ser livre.

O texto é fartamente recheado com exemplos, como o do jovem que deve escolher entre ficar com a mãe doente ou se inscrever nas fileiras da Resistência francesa contra o nazismo. O que ocorre é, no fundo, a percepção de que a subjetividade também apreende não apenas a si mesmo, mas também apreende o outro, o que não a faz, portanto, solipsista. Por isso, o existencialismo parece, aos olhos de Sartre, dar um salto adiante da moderna filosofia de Kant e Descartes: 
O outro é indispensável à minha existência tanto quanto, aliás, ao conhecimento que tenho de mim mesmo. Nessas condições, a descoberta da minha intimidade desvenda-me, simultaneamente, a existência do outro como uma liberdade colocada na minha frente, que só pensa e só quer ou a favor ou contra mim. Desse modo, descobrimos imediatamente um mundo a que chamaremos de intersubjetividade e é nesse mundo que o homem decide o que ele é e o que são os outros. (SARTRE, 1987, 16)

Aqui Sartre afirma que não existem essências universais ou natureza humana mas, ao mesmo tempo, afirma a universalidade da condição humana. Logo, a mentira da má-fé é exatamente não escolher e o que o autor francês parece buscar, tal como fez Kierkegaard em sua época, é a autenticidade. Assim sendo, o homem não é meta do existencialismo tal como o era no humanismo clássico. $\mathrm{O}$ homem é, na realidade, um projeto por se fazer. Logo, "não existe outro universo além do universo humano, o universo da subjetividade humana" (SARTRE, 1987, 21). Contudo, em sua busca por constituir um eu, o existencialismo ateu se difere do existencialismo cristão que, segundo pensa Sartre, é desesperado:

O existencialismo não é tanto um ateísmo no sentido em que se esforçaria por demonstrar que Deus não existe. Ele declara, mais exatamente: mesmo que Deus existisse nada mudaria; eis nosso ponto de vista. Não que acreditemos que Deus exista, mas pensamos que o problema não é o da sua existência; é preciso que o homem se reencontre e se convença de que nada pode salvá-lo dele próprio, nem mesmo uma prova válida da existência de Deus. Nesse sentido, o existencialismo é um otimismo, uma doutrina da ação, e só por má-fé é que os cristãos, confundindo o seu próprio desespero com o nosso, podem chamar-nos de desesperados. (SARTRE, 1987, 22)

Na sua busca subjetiva do tema do eu em Sartre talvez fosse importante uma melhor comparação com o tema do eu tal como tratado por ele e por Kierkegaard em A Doença para a Morte, coisa que faremos na terceira parte do nosso artigo, pois, a despeito de parecem muito diferentes, ali Kierkegaard também refuta a possibilidade de provas para o cristianismo, o que o aproximaria de 
Sartre ao menos numa parte da reflexão. Assim, o tema do universal singular é absolutamente central na reflexão dos dois pensadores.

É dentro desse mesmo espírito que julgamos estar situado o texto $O$ universal singular. Tal trabalho foi escrito por Sartre para o colóquio Kierkegaard vivant, promovido pela UNESCO e alusivo aos 150 anos do nascimento do pensador, isto é, em 1963, a despeito do evento haver se dado efetivamente de 21 a 23 de abril de 1964. Em tal oportunidade, pensadores como Gabriel Marcel, Karl Jaspers, Heidegger e outros, além do próprio Sartre, apresentaram suas reflexões e debateram sobre a herança da filosofia kierkegaardiana para o nosso tempo. Tais trabalhos se constituem, ainda no momento atual, um das contribuições críticas mais significativas ao autor de Copenhague produzidas no século XX.

A primeira indagação posta por Sartre na sua reflexão é acerca do próprio título do colóquio, isto é, o que significa dizer que Kierkegaard está vivo? Na verdade, dizer que um autor está vivo pressupõe sabermos que ele está morto e que, para nós, faz sentido afirmar sua vida ou ainda buscar entender como ele pode continuar vivo entre nós a despeito de estar morto. Feita tal primeira digressão e abertura da sua apresentação, Sartre avança para uma questão mais significativa na análise da filosofia de Kierkegaard: podemos obter da história algum tipo de certeza eterna? Pode-se encontrar nesse ponto de partida um interesse distinto do histórico? Pode-se fundar uma felicidade eterna sobre um saber histórico?

Tais questões não são nenhuma novidade na filosofia e menos ainda foram criadas por Sartre ou mesmo Kierkegaard. A rigor elas trazem no seu bojo dois problemas centrais. O primeiro é que ela reflete na verdade o contexto de um debate acerca da importância da história no século XIX. Em outras palavras, por forte inspiração hegeliana, refletir ou fazer filosofia significa reconstituir a história do pensamento humano e seguindo tal trilha encontrar o sentido, a realidade e, tal como pensou Hegel, o absoluto. $\mathrm{O}$ segundo ponto é que a felicidade eterna só pode ser entendida em plenitude no âmbito do cristianismo. Seguindo a trilha das Sagradas Escrituras e dos primeiros pais da Igreja, Santo Agostinho é quem talvez melhor o tematizou no decorrer de boa parte de sua obra e, inclusive, dedicou-lhe um tratado especial com o significativo título de $\mathrm{A}$ Vida Feliz ${ }^{3}$. Em outras palavras, faz sentido no âmbito do cristianismo a busca por felicidade eterna que não é capaz de estar contida no processo histórico-mundial.

Tais teses são recuperadas por Kierkegaard, sob a pena do pseudonímico autor Johannes Climacus, tanto nas Migalhas filosóficas como em Pós-Escrito

3 Agostinho, Solilóquios e A Vida Feliz, Paulus, São Paulo, 1998. 
às Migalhas filosóficas. Em ambas as reflexões o autor kierkegaardiano repete aqui as mesmas formulações pontuadas por Sartre e de fundo claramente agostiniano e cristão. Por isso, na segunda parte do presente artigo, investigaremos um pouco melhor o problema da história e dos seus limites no entender de Kierkegaard tendo em vista especialmente tais obras.

Tal discussão acerca da história é, na verdade, decorrência da interpretação hegeliana que produz uma equivalência entre conhecer e saber, enquadrando ambos numa perspectiva sistemática. Seguindo a tradicional metafísica sujeito-objeto, a visão do pensador alemão tenta compreender tudo sob tal signo. Por isso, no entender de Sartre, Kierkegaard se vê impelido a avançar tanto nas $\mathrm{Mi}$ galhas filosóficas como no Pós-Escrito às Migalhas filosóficas, mas também em A Doença para a Morte, que abordaremos na parte terceira do presente artigo, para uma nova tentativa de afirmar temas como a interioridade e a subjetividade. Assim, parece-nos bastante estratégico uma longa parte dedicada à subjetividade no Pós-Escrito às Migalhas filosóficas e uma tentativa sempre de compreendê-la tanto a partir do seu elemento mais primordial grego, a saber, Sócrates, com quem Kierkegaard praticamente inicia as suas reflexões na tese sobre $O$ Conceito de ironia e com quem seguirá até praticamente os passos finais da sua existência, quando novamente o pensador ateniense será o seu modelo para criticar severamente a união entre Igreja e Estado no contexto dinamarquês, tal como se pode constatar na sua última - e inacabada obra - O Instante.

Sabedor de tudo isso, Sartre percebe com argúcia que os pseudônimos são centrais na discussão acerca da filosofia kierkegaardiana. É que mesmo sua crítica ao histórico só pode ser efetivamente concretizada em virtude de Kierkegaard ser, ele próprio, histórico. Contudo, de modo paradoxal, para usar um termo tão caro ao pensador dinamarquês, com sua morte, o legado kierkegaardiano parece tomar um outro rumo:

Assim, Søren Kierkegaard, vencido pela morte e recuperado mediante o saber histórico, triunfa no mesmo momento em que naufraga, demonstrando que a história não pode recuperá-lo: morto, segue sendo o escândalo insuperável da subjetividade; conhecido até o fundo, escapa à história pelo fato mesmo de que esta constitui sua derrota e de que ele viveu essa derrota por antecipado. Dito brevemente: Kierkegaard escapa à história porque é histórico. (SARTRE, 1980, 29) 
No entender de Sartre, Kierkegaard não deixa de fazer filosofia, mas a faz de modo anti-filosófico. Sua busca pelo saber que constitui a filosofia, só pode ser compreendida como uma busca fora da temporalidade, pois seguindo a pista cristã e agostiniana, o homem não pode mais alcançar a verdade pelos seus esforços e, nesse sentido, buscar os caminhos da consciência a partir de si ou, a partir daqui, tentar reconstituir a interioridade ou a subjetividade, pode ser um projeto fracassado de saída. Por isso, Sartre interpreta a tentativa kierkegaardiana como uma espécie de começo humano da filosofia, ao passo que na filosofia de Hegel residiria um começo não-humano, o que, inclusive, o aproximaria de filosofias contemporâneas como a de Merleau-Ponty, por exemplo: "Contra o começo não-humano e fixo de Hegel, Kierkegaard propõe um início móvel, condicionado-condicionante, cujo fundamento é muito parecido ao que Merleau-Ponty denominava a "envoltura""4 (SARTRE, 1980, 29). Em outras palavras, estamos envolvidos, o Ser está tanto por detrás de nós como à nossa frente.

Com efeito, o cristianismo dinamarquês percebido por Kierkegaard é tanto o visível, que o formou, como o invisível, que segue também à sua frente. Por isso, sua crítica a partir da interioridade do subjetivo é também um dilema diante da história. Na verdade, Kierkegaard está em busca de uma coisa que atormentou gerações de cristãos: a autenticidade e a angústia de ter que escolher diante de Deus, tal como ocorreu com Adão no paraíso e tal como o pensador tentará compreender tal dilema em $O$ Conceito de angústia, que abordaremos na próxima parte de nosso trabalho. Para Sartre, a angústia de Adão se encontra com a possibilidade, outro tema fundamental na construção kierkegaardiana: "A angústia é, assim, abandono do ser à possibilidade proibida de eleger-se finito, abandono causado por um brusco retrocesso do infinito. É na interiorização desse desamparo e termina na realização do único possível a Adão desamparado: a eleição do finito" (SARTRE, 1980, 38).

Por fim, chegando ao final de seu texto $O$ universal singular, Sartre avalia que Kierkegaard é um mestre dos disfarces e da linguagem, sempre se utilizando da ironia e da comunicação indireta para transmitir os conteúdos almejados. Muito mais do que uma estratégia, trata-se aqui de uma posição de conteúdo filosófico, isto é, do que pode ser compreendido e não pode ser compreendido, do que pode ser revelado e do que não pode ser revelado. Assim, respondendo a própria pergunta inicial por ele posta, isto é, que sentido faria dizer que Kierkegaard está vivo, Sartre afirma: "Se eu posso chegar a ser Kierkegaard,

4 Sartre está referindo aqui a algumas teses do pensador francês desenvolvida em $O$ Visível e $o$ Invisível, que não teremos tempo aqui de avaliarmos adequadamente.

Merleau-Ponty, M. O Visivel e o invisível, Editora Perspectiva, São Paulo, 1971. 
e que esse já era, em seu ser, uma premonição de todos nós" (SARTRE, 1980, 45). Ser Kierkegaard não é copiar Kierkegaard, pois tal coisa seria uma traição à subjetividade tal como proposta pelo pensador e, no fundo, recairia no problema objetivo da verdade e numa espécie de conteúdo positivo. Contudo, apesar de ser um sujeito único, o indivíduo singular como prezava em dizer (e como Sartre aqui repete), Kierkegaard é, de modo paradoxal, cada um de nós em dada medida, pois "em cada um de nós Kierkegaard se outorga e se recusa, como até enquanto vivia; é minha aventura e segue sendo para os demais" (SARTRE, 1980, 48). Em outras palavras, Kierkegaard serve não por ele mesmo ou por nos ensinar algo de modo objetivo, mas pode nos ensinar algo se estivermos dispostos ao exercício da nossa subjetividade. Por isso, pensar ao modo de Kierkegaard é, talvez, buscar a si próprio. Desse modo, o indivíduo singular é importante. Afinal, "Kierkegaard foi o primeiro que mostrou que o universal entra como singular na história, na medida em que o singular se institui nela como universal" (SARTRE, 1980, 42).

\section{O problema da subjetividade e da história em Kierkegaard: $O$ Conceito de angústia, as Migalhas filosóficas e o Pós-Escrito às Migalhas filosóficas}

Kierkegaard escreve ao mesmo tempo tanto o Conceito de angústia como as Migalhas filosóficas. Ambas as obras são de 1844 e são separadas por 4 dias de publicação. A primeira é assinada pelo pseudônimo autor Vigilius Haufniensis e é efetivamente publicada em 17 de junho de 1844, a segunda por Johannes Climacus e é publicada em 13 de junho de 1844. Tal fato parece claramente apontar que o problema do pecado é central para ambas, mas o que difere é a solução, a perspectiva de leitura proposta. Em O Conceito de angústia o tema é visto pela perspectiva da liberdade do indivíduo que deve decidir, o que torna tal obra, como vimos no item anterior, bastante atraente para a perspectiva da filosofia existencial de Sartre e, ao mesmo tempo, a abordagem sobre o nada e os problemas do espírito a aproximam igualmente de uma abordagem mais de cunho heideggeriana e, não fortuitamente, o pensador alemão parece ter tido nessa obra grande interesse. Contudo, ao mesmo tempo, $O$ Conceito de angústia também trata, como bem salientou Theunissen, de um problema espiritual, diferente do problema do eu, coisa que será feita pela Doença para a Morte, que veremos na próxima parte do nosso artigo: "O Conceito de angústia enfatiza o espírito e não eu porque ainda adere à ideia de que os indivíduos são 
destinados a algo extremamente individual. O livro sobre o desespero, em contraste, parte da antropologia clássica" (Theunissen, 2005, 25) Já as Migalhas filosóficas se constitui numa espécie de tentativa de Climacus em tentar provar o cristianismo ao modo grego e em tentar perceber até que grau cristianismo e paganismo são distintos na sua compreensão da verdade pois, mesmo que a obra não seja confessadamente cristã, ele trabalha de modo subliminar com vários dos pressupostos do cristianismo e vai comparando cada um desses com um possível modelo grego para, ao final, concluir que são dois modelos irreconciliáveis em virtude do pecado ter afetado a condição do homem em possuir e em buscar a verdade.

Aos olhos de Haufniensis, Adão oscila entre a angústia, a inocência e a culpa. Desse modo, parece impossível, segundo avalia o pensador dinamarquês explicar o fato do pecado. A única coisa possível é a aproximação da angústia que o cerca. A angústia é sempre uma possibilidade de liberdade, a liberdade como realidade, pois a liberdade plena é algo nunca possível. Não fortuitamente três temas estão presentes o tempo todo nas reflexões do pensador: a consciência de si, a liberdade, o pecado. A angústia aparece, portanto, como a possibilidade da possibilidade de liberdade e como forma paradoxal de fé. Note-se que, não sem propósito, o tema da consciência de si é aqui uma resposta kierkegaardiana ao posicionamento hegeliano, notadamente aquele exposto na Fenomenologia do espírito. Por isso, Lacan, leitor de Kierkegaard e de Hegel, já observou com argúcia a relação que deve haver entre esses dois pensadores no que concerne a angústia: "A verdade da formulação hegeliana, quem a dá é Kierkegaard" (LACAN, 2005, 35).

Antes de entrar propriamente na angústia, o autor de $O$ Conceito de angústia deve explicar algo sobre a inocência e, nesse sentido, sua explicação parece exemplar:

A inocência é a ignorância. $\mathrm{Na}$ inocência, o ser humano não está determinado como espírito, mas determinado psiquicamente em unidade imediata com sua naturalidade. O espírito está sonhando no homem. Tal interpretação está em perfeita concordância com a da Bíblia que, ao negar ao homem em estado de inocência o conhecimento da diferença entre o bem e o mal, condena todas as fantasmagorias católicas sobre o mérito. (KIERKEGAARD, 2010, 44-45) 
Se o que existe é a inocência e nele não pode ainda haver nem escolha e nem qualquer capacidade de julgamento, o que se afirma, a partir disso, só pode ser o nada, coisa que Heidegger bem percebeu em sua leitura de Kierkegaard. A inocência, antes de se tornar culpada, cede seu lugar para a angústia que, por sua vez, só pode ser afirmada enquanto angústia de nada:

Nesse estado, há paz e repouso, mas ao mesmo tempo há de diferente que não é discórdia e luta; pois não há nada contra o que lutar. Mas o que há, então? Nada. Mas, nada que efeito tem? Faz nascer angústia. Sonhando, o espírito projeta a sua própria realidade efetiva, mas esta realidade nada é, mas este nada a inocência vê continuamente fora dela. (KIERKEGAARD, 2010,45)

Logo, a angústia é uma determinação espiritual e ocupa lugar importante na psicologia. É ela quem estabelece a distinção entre o eu e outro eu de mim, a tal intersubjetividade que Sartre percebeu muito bem em $O$ existencialismo é um humanismo. Sua realidade surge como uma possibilidade e jamais pode ser comparada com temor, que se relaciona a algo exato e concreto, coisa que Sartre também percebe com clareza em $O$ Ser e o nada. A angústia é algo que diferencia homens e animais, isto é, é uma determinação humana à capacidade de escolher e se angustiar diante do escolhido:

A angústia é uma forma imperfeita da liberdade, ela se configura como algo intermediário entre a inocência e a culpa. Por isso, a chave kierkegaardiana para a explicação da angústia reside na afirmação do espírito como um terceiro elemento entre a síntese alma e corpo: "O homem é uma síntese do psíquico e do corpóreo. Porém, uma síntese é inconcebível quando dois termos não se põem de acordo num terceiro. Este terceiro é o espírito" (KIERKEGAARD, 2010, 47).

Logo, o pecado de Adão se afirma aqui como a vontade e como desejo reprimido. Trata-se da vitória do nada da angústia, algo que precede a consciência. Aqui não se pode afirmar a consciência de Adão. Quando Deus o proíbe de comer os frutos da Árvore do Bem e do Mal, ele sequer poderia distinguir o que era bom e mau. A rigor tal distinção só faz sentido depois dele ter efetiva- 
mente saboreado os frutos. Do mesmo modo, ele também não é ainda capaz de entender a sentença divina que o ameaça de morte se desrespeitar a lei. Para Haufniensis, o pavor de Adão só pode derivar da angústia:

Às palavras da proibição seguem-se as palavras da sentença: "Certamente tu morrerás". O que significa morrer, Adão, naturalmente, não compreende de jeito nenhum, mas, por outro lado, nada impede, se aceitarmos que isso lhe foi dito, que tenha recebido a representação de algo horrível. Pois até o animal é capaz de, neste sentido, entender a mímica e o movimento da voz do que fala, sem ter entendido a palavra. Se acaso se admite que o desejo desperta a proibição, então também se deve admitir que a ameaça do castigo desperta uma representação assustadora. No entanto, isso confunde as coisas. O horror aqui apenas se converte em angústia, pois Adão não compreendeu o enunciado e tem portanto novamente apenas a ambiguidade da angústia. A infinita possibilidade de ser-capaz-de, que a proibição despertou, aproxima-se agora ainda mais porque esta possibilidade manifesta uma outra possibilidade como sua consequência. (KIERKEGAARD, 2010,48)

Notemos, portanto, que a riqueza da história de Adão reside num tema muito caro à reflexão kierkegaardiana: a saber, o tema da possibilidade, que também acompanhará a reflexão desenvolvida por Climacus em Migalhas filosóficas e em Pós-Escrito às Migalhas filosóficas.

O problema das Migalhas filosóficas, já percebido com clareza também por Sartre no seu texto $O$ indivíduo singular reside em torno da pergunta: será possível basear a felicidade eterna em verdades contingentes ou de fato? Climacus, o pseudônimo autor da obra, ao pensar tal questão, está influenciado por Lessing que, por sua vez, se encontra influenciado por Leibniz, pioneiro nessa divisão entre verdade de fato e verdade lógica. Kierkegaard trabalha, nesse ponto, com os dados do cristianismo, porém não de um modo confesso, mas apenas como um modelo teórico criado pelo pseudônimo. Por ser o cristianismo uma verdade de fato e não uma verdade lógica, será preciso que ele opere com o conceito de salto. Aliás, essa concepção de salto, a rigor, é de Lessing e será 
usada novamente em outros momentos da obra kierkegaardiana, pista que não poderemos aqui aprofundar 5 .

Todavia, essa distinção entre as verdades e a abordagem sobre a felicidade eterna não constituem o mote principal da obra, mas apenas o pano de fundo para uma questão que já havia sido abordada no primeiro trabalho de Kierkegaard, isto é, no Conceito de ironia de 1841: pode-se ensinar e aprender a virtude? Observemos que, nas Migalhas filosóficas, troca-se o termo virtude, usado anteriormente no Conceito de ironia, pelo equivalente existencial verdade. Surge, a partir dessa pergunta, o pensamento platônico de reminiscência somado com a tese socrática que afirma que o homem já está de posse da verdade. Se prevalecer a tese da reminiscência, de que o homem já sabe previamente, bastando apenas a rememoração e a tese socrática, de que o homem já está na verdade, o instante se tornaria inútil. Com efeito, ele não seria mais do que uma mera ocasião.

Ora, a proposta alternativa de Kierkegaard é exatamente o contrário disso, pois nela o instante é decisivo, pois é também o momento da subjetividade. O que diferirá a proposta kierkegaardiana da proposta socrática é que a primeira pressupõe que o homem não está de posse da verdade, pois esse se encontra em estado de pecado, tal como foi igualmente explorado no Conceito de angústia. Desse modo, Clímacus utiliza categorias gregas para a construção do seu modelo alternativo e também para provar até onde é possível utilizar essas categorias. No fundo, a proposta alternativa kierkegaardiana é uma crítica tanto do idealismo platônico como do idealismo hegeliano. O idealismo hegeliano não passaria de uma consequência do idealismo platônico. Porém, o problema das Migalhas filosóficas não possui solução, visto que ele deve ser encarado pela perspectiva da fé. Tal pressuposto aparece no próprio projeto teórico de Clímacus e, com muita probabilidade, é bastante tributário do argumento ontológico de Santo Anselmo, onde o ponto de partida reside na fé e não no conhecimento.

Logo, o Sócrates de Kierkegaard nas Migalhas filosóficas é bastante diferente do Sócrates do Conceito de ironia. Nas Migalhas filosóficas, o Sócrates de Kierkegaard, sob a pena de Clímacus, representa o homem comum (pagão) em oposição ao homem renascido (cristão). O Sócrates de Clímacus nas Migalhas filosóficas é aquele que consegue o máximo na relação com os demais homens. Porém, ainda está bastante distante da proposta alternativa ideal formulada por Clímacus.

5 Há na segunda parte do primeiro volume do Pós-Escrito às Migalhas filosóficas um elogio a Lessing na seção onde Climacus trata da subjetividade. Recomenda-se tal leitura para um maior aprofundamento na temática.

KIERKEGAARD, S.A. Pós-Escrito às Migalhas filosóficas - volume I, Editora Vozes, Petrópolis, 2013. 
A pergunta que motiva As Migalhas é a seguinte: Em que medida se pode aprender a verdade? Tal pergunta é antiga: ela já está presente no diálogo $M \hat{e}-$ non de Platão. Procurar a verdade é admitir que ela anteriormente não existia em nós. Contudo, procurar aquilo que sabemos é impossível, visto que já sabemos. Já procurar pelo que não sabemos é inviável, uma vez que nem sequer sabemos aquilo que procuramos. Era essa é a dificuldade com a qual a filosofia socrática se deparava.

Segundo a concepção socrática, para saber a verdade basta que o homem relembre, isto é, a verdade já está no próprio ser, ela apenas se encontra adormecida. Essa será a prova da pré-existência da alma dada pelo Mênon, também conhecida como teoria da reminiscência. Ora, se esse homem está de posse da verdade (que está apenas adormecida nele), ele pode alcançá-la pelos seus próprios esforços. Por isso, nessa concepção, o ponto de partida temporal é um nada, o instante não tem a mínima importância.

O instante não tem importância, pois nele descubro que sabia eternamente a verdade. Sendo assim, esse instante é reabsorvido e incorporado pelo tempo e, por isso, eu jamais poderei encontrá-lo, visto que ele se perde no tempo. Para Kierkegaard, o instante só pode ser decisivo se não for entendido à maneira socrática. Convém, por isso, examinar também dois outros termos que aparecem em Kierkegaard (e na filosofia socrática): discípulo e mestre.

$\mathrm{Na}$ visão kierkegaardiana, o discípulo não é nem mesmo o que ele procura, visto que ele está fora da verdade, ou melhor ainda, ele é a não-verdade. O mestre é necessário ao discípulo por causa disso, ou seja, para lembrá-lo que ele é a não-verdade. O discípulo jamais conseguiria chegar até a verdade pelos seus próprios esforços.

O mestre deve levar o discípulo não somente até à verdade, mas também deve dar a condição para que ele possa entendê-la. Afinal, se o discípulo tivesse a condição, bastaria que ele se lembrasse da verdade (o que seria socrático). O discípulo também não fornece ao mestre a condição para que ele próprio entenda a verdade, porém só pode haver ensino porque essa condição está presente. $\mathrm{O}$ mestre pode transformar o discípulo, mas não pode recriá-lo. Somente o deus pode recriar o discípulo. Afinal, foi o deus quem o criou e lhe deu a condição de compreender.

Logo, o instante tem importância decisiva, pois o discípulo está sem a condição de compreender ou foi, de alguma maneira, despojado dela. Observemos que isso não ocorreu por vontade do deus e nem foi obra do acaso, mas ocorreu, segundo Kierkegaard, por culpa do próprio discípulo. Ele não somente está fora da verdade como polemiza com ela. $\mathrm{O}$ discípulo perde a sua condição por sua própria culpa, por estar, conforme a concepção kierkegaardiana, em estado de pecado. 
Sendo assim, o mestre só pode ser o próprio deus, que é o único capaz de dar a condição e a verdade. Como poderemos denominar esse mestre, visto que ultrapassamos o próprio conceito (até então socrático) de mestre? Existem, para o deus-mestre, segundo Kierkegaard, quatro atributos: Salvador, Libertador, Reconciliador e Juiz.

Ele é Salvador, pois salva o discípulo da não-liberdade, salvando-o de si mesmo. Ele é Libertador, visto que liberta aquele que era prisioneiro de si mesmo. Ele é Reconciliador, pois reconcilia o discípulo que se tornara culpado pelo uso de sua não-liberdade, isto é, o mestre lhe dá a condição e a verdade, retirando a cólera suspensa sobre a culpa. Ele é Juiz, pois se novamente adquirimos a condição de compreender, seremos responsáveis pelas nossas ações e estaremos conscientes delas.

O instante possui também uma natureza particular e mesmo o instante religioso é breve e singular, como todos os demais. Contudo, ele é, segundo Kierkegaard, decisivo e composto de eternidade plena. O instante é, nessa concepção, uma plenitude dos tempos, isto é, ele é kayros (tempo propício) e não krónos (tempo decorrido). Notemos que desse primeiro conceito de instante derivam outros. Somente com a presença do deus no tempo é que se pode entender o conceito de instante em Kierkegaard.

Ao ir da não-verdade para a verdade, o discípulo se torna novo homem. Ocorre nele uma mudança, uma conversão. Ele se torna consciente de sua culpa. Ele pode, desse modo, olhar para trás seguindo em frente. É certo que o discípulo foi criado pelo deus, porém, ao se converter, ele sai do não-ser para o ser, ele renasce e supera o estado de pecado. No instante desse renascimento ele se torna consciente, pois seu estado anterior era o do não-ser. Notemos o quanto tal ênfase de ir do não-ser para o ser foi apropriado no século XX por um tipo de filosofia existencialista tal como aquela proposta por Sartre e mesmo por uma filosofia do ser tal como o pensou Heidegger.

As consequências dessa mudança, do não-ser para o ser, são as seguintes: a) essa decisão do deus é eterna, ao se realizar no tempo, se torna o instante; b) o instante nasce do choque entre decisão e ocasião, isto é, é decisão eterna para o deus e ocasião para o homem. Porém, com a ação do deus no tempo, isso se torna mais do que ocasião para o homem, transforma-se em instante decisivo; c) Ocorre a dialética do instante. Em Sócrates é possível observar o instante e sequer discerni-lo. Por isso é que, para o filósofo ateniense, o discípulo é a verdade, e o instante da ocasião é a aparência; d) o instante socrático é falso e 
o instante da decisão é loucura. Afinal, se há uma decisão para ser tomada, o discípulo se tornaria a não-verdade. É exatamente isso que torna necessário o começo do instante; e) o instante é, de fato, decisão da eternidade: o deus no tempo, nascido, crescido e sofrendo por amor aos homens; f ) o instante é o paradoxo, isto é, algo que não pode ser explicado racionalmente, senão retornaremos ao modelo socrático.

Em outras palavras, o instante é a plenitude dos tempos, visto que Deus está no tempo (paradoxo). O instante é também composto da decisão eterna do deus e da decisão humana (passagem do não-ser para o ser).

Portanto, segundo Kierkegaard, a verdade jamais pode ser encontrada no ser humano. Com o estado de pecado, ocorre uma separação e distância entre o homem e o deus, o homem perde a sua condição original. O homem precisa de algo mais do que um parteiro, como era Sócrates, para tirar de si mesmo o que ele já é. Logo, algo deve vir de fora, algo deve vir do exterior para esse homem. O deus deve ser o Salvador, deve ser o algo exterior que possibilitará uma nova vida ao homem. Essa é a diferença entre o deus (que é Mestre e Salvador) e Sócrates, que é somente um mestre existencial. O Salvador representa o fim da distância entre o homem e o deus, ele é a verdade e fornece a condição para que o homem possa compreendê-la. Ele é a própria possibilidade de compreensão que surge no reconhecimento da diferença entre o deus (Mestre e Salvador) e o homem.

Contudo, no final das Migalhas filosóficas, Climacus se depara com um problema que ainda não conseguiu resolver ou que parece até mesmo sem solução: o problema da história e do cristianismo. Mesmo tendo gastado boa parte de sua reflexão pensando sobre o tema do discípulo contemporâneo e o que significava ser contemporâneo para o âmbito do cristianismo, Climacus não consegue responder a contento a uma pergunta tão importante para o século XIX, a saber, seria a história do cristianismo o próprio cristianismo? Por isso, não sem propósito, promete, até mesmo de um modo aparentemente displicente, continuar tal reflexão num futuro próximo. O que é feito efetivamente com a produção de Pós-Escrito às Migalhas filosóficas, obra de grande fôlego filosófico e capital para boa parte da reflexão existencialista sobre Kierkegaard no século XX, incluindo aqui a filosofia de Sartre.

No Pós-Escrito às Migalhas filosóficas de 1846, portanto escrito dois anos depois das Migalhas filosóficas, logo na primeira parte do primeiro volume $O$ problema objetivo da verdade do cristianismo o primeiro capítulo se denomina A consideração histórica. Ali, em três divisões, a saber, A Sagrada Escritura, 
A Igreja e Os muitos séculos como prova da verdade do cristianismo, Climacus avalia criticamente a interpretação protestante do Sola Scriptura, investiga mais a fundo o tema do cristianismo triunfante e do cristianismo militante. O primeiro tipo seria o do cristianismo vitorioso, ligado ao poder e, portanto, aquilo que se denominou cristandade, conceito tão fortemente criticado pelo filósofo. $\mathrm{O}$ segundo tipo, é o cristianismo subjetivo, da escolha, da possibilidade, ou seja, o cristianismo militante. $\mathrm{O}$ pensador enxerga aqui o que há de mais autêntico no cristianismo. Por fim, na última divisão do capítulo, o filósofo percebe de modo crítico que os muitos séculos do cristianismo não podem provar sua verdade cabal na medida em que o cristianismo deve ser, antes de mais nada, uma verdade para um sujeito concreto e existente, que opta por ele dentro do tempo, que o toma como uma possibilidade.

Desse modo, toda a segunda parte do primeiro volume do Pós-Escrito às Migalhas filosóficas é voltada para a análise do problema subjetivo ou, em outras palavras, almeja entender a relação do sujeito com a verdade do cristianismo, ou melhor dizendo, como ocorre o processo do tornar-se cristão, aquilo que o projeto das Migalhas filosóficas, usando bastante da filosofia aristotélica, denominou como devir. Mais uma vez, mesmo sabendo dos diferentes registros interpretativos, podemos perceber aqui o quanto tal tema parece instigante e apropriado para uma reflexão como aquela postulada pela filosofia da existência de Sartre no século XX. Não se trata, evidentemente, de uma subjetividade arbitrária, mas de uma subjetividade que toma a verdade como uma verdade para si, como uma apropriação, o que parece muito significativo. Por isso, de muito espirituoso, Climacus parece ter razão sobre a incerteza da história apenas entendida ao modo objetivo: "Se todos os anjos unissem seus esforços, eles ainda assim só seriam capazes de produzir uma aproximação, porque no que se refere ao conhecimento histórico uma aproximação é a única certeza (KIERKEGAARD, 2013, 35).

Há, contudo, um outro tema bastante caro para a filosofia kierkegaardiana e, sem dúvida alguma, também para a reflexão da filosofia da existência no século XX: o tema do eu. Afinal, não se pode pensar a contento em subjetividade sem uma filosofia do eu e mesmo a moderna psicanálise, por exemplo, necessita disso. Desse modo, uma melhor investigação sobre isso nos coloca frente a frente com a obra kierkegaardiana A Doença para a Morte, que abordaremos a partir da divisão abaixo. 


\section{O eu kierkegaardiano: A Doença para a Morte}

A Doença para a Morte, obra escrita pelo pseudônimo Anti-Climacus em 1849 é uma capital para a discussão acerca do problema do eu e não apenas para se discutir o problema do desespero como talvez, de modo errôneo, se possa imaginar. Por meio da pena desse pseudônimo autor estritamente cristão, se investigará o problema do pecado em sua relação direta com o problema do eu. Note-se que a mesma questão já norteará também, com diferentes registros, às Migalhas filosóficas, $\mathrm{O}$ Conceito de angústia, $\mathrm{O}$ Pós-Escrito às Migalhas filosóficas e, aliás, persistirá numa obra igualmente assinada por Anti-Climacus em 1850, a saber, O Exercício do cristianismo, onde o cristianismo é tomado como uma prática e como um projeto cabalmente oposto ao que teria significado o projeto socrático ou pagão que, por sua vez, desembocaria no projeto iluminista e racional. Além disso, como bem enfatiza Jon Stewart, o pseudônimo não apenas faz um diagnóstico de sua época, mas também propõe uma alternativa ao desespero:

\footnotetext{
Kierkegaard introduz um novo autor pseudônimo, chamado Anti-Climacus, que enumera as diferentes formas de desespero das quais os humanos sofrem. Ele tenta compreender o desespero como uma forma de pecado, e, no fim, recomenda a aceitação do cristianismo como solução para o desespero (STEWART, 2017, 233).
}

A obra se divide em duas grandes partes. A primeira é denominada $A$ enfermidade mortal é desespero. A segunda é denominada $O$ desespero é o pecado. Ambas são precedidas por uma espécie de prólogo denominado A enfermidade mortal ou do desespero e o pecado - uma exposição cristã-psicológica para edificar e despertar. Não será nosso intuito aqui abordar o prólogo em si mas, de modo, curioso devemos atentar para duas pequenas coisas: primeiro, trata-se de uma exposição que almeja conjugar psicologia e cristianismo, ou seja, o problema do eu será visto aqui pela conjunção dessas duas perspectivas. Segundo, ao contrário dos objetivos da filosofia hegeliana, que sempre evitava a edificação, o prólogo advoga claramente a tese da edificação e do despertamento, o que parece aproximar o autor do cerne da práxis do cristianismo e o coloca em absoluta concordância com a escritura de discursos, como muitos feitos por ele, para a edificação dos seus ouvintes. Em outras palavras, a filosofia, aos olhos de Kierkegaard, não deve evitar a edificação mas, ao contrário, estimulá-la. 
Não será um objetivo aqui a investigação minuciosa da primeira parte de $A$ Doença para a Morte. Contudo, devemos ressaltar que nela afirma-se o problema do eu e do desespero. Por intermédio de uma divisão de toda essa parte em três livros, os quais não mencionaremos aqui para não perdermos nosso foco investigativo, o problema do eu será fortemente avaliado pela ótica da filosofia idealista do século XIX, especialmente a filosofia de Fichte. Por isso, todo o livro I é, na verdade, uma leitura a partir dos pressupostos da tese $\mathrm{Eu}=\mathrm{Eu}$ do pensador alemão e uma tentativa de entender o homem como um síntese e uma relação que se relaciona consigo mesma. Por isso, também aqui o léxico se utiliza fartamente de expressões típicas de tal tipo de idealismo como, por exemplo, possibilidade e realidade. Já no livro II afirma, num número menor de páginas, a universalidade dessa enfermidade chamada desespero. Por fim, os livros III e IV abordam de forma bastante detalhada os problemas da síntese e da consciência, revelando ambos um substrato bastante calcado na filosofia hegeliana do período e no seu legado dentro do quadro teórico do idealismo alemão.

A segunda parte da obra, que objetivamos avaliar aqui mais detalhadamente do que a primeira, é dividida em dois livros. O primeiro é denominado $o$ desespero é o pecado. O segundo é denominado a progressão do pecado. Os dois livros são divididos, por sua vez, em capítulos e apêndices, que não nos interessam aqui detalhar. A abertura da segunda parte logo enfatiza o pecado como pecado diante de Deus, isto é, retoma aqui o tema da consciência que foi bastante explorado filosoficamente em toda a primeira parte de $A$ Doença para a Morte: "Há pecado quando diante de Deus, ou tendo a ideia de Deus, alguém não quer desesperadamente ser si mesmo, ou desesperadamente quer ser si mesmo" (KIERKEGAARD, 2008,103). A ênfase é posta aqui no estar "diante" de Deus. Temos, portanto aqui, um problema de consciência.

Anti-Climacus é sabedor que existem graus de consciência do eu e por isso tratou tão detalhadamente do tema na primeira parte do seu tratado, sabendo que estar "contra" ou "diante" de Deus pode fazer aqui toda a diferença. No entender de Glenn, a temática do eu em Kierkegaard que aqui ressoa é, na verdade, um eco anterior que pode, inclusive, ser percebido no todo de sua obra, especialmente nas que lhe antecederam e nas perspectivas futuras que abre ao seu leitor:

A definição que Kierkegaard dá do eu é um exemplo notável de sua habilidade dialética e literária. No entanto é mais do que isso; fornece uma chave e a estrutura para entender o conteúdo de A Doença para a Morte, bem 
como os 'estágios' da existência descritos em seus primeiros escritos pseudônimos. É uma parte crucial dos trabalhos que foram destinados a ajudar seus leitores no caminho para a autocompreensão e autorealização (GLENN, 1987, 21).

Desse modo, sua tese é de que, paradoxalmente, quanto maior for a ideia de Deus mais eu existirá e, em contrapartida, quanto menor for a ideia de Deus menos eu existirá: "Nosso eu individual e concreto somente chega a ser um eu infinito mediante a consciência de que existe diante de Deus; e este eu é cabalmente o que se põe a pecar diante de Deus (KIERKEGAARD, 2008, 108)

Nesse sentido é que o pseudônimo autor compreende que o paganismo é o equivalente ao homem natural e define o pecado como quando se quer e quando não se quer ser si mesmo diante de Deus. Em outras palavras, há uma estreita relação entre fé e pecado e por isso a fé "consiste em que o eu, sendo si mesmo e querendo sê-lo, se fundamenta lúcido em Deus (KIERKEGAARD, 2008, 110). Logo, a fé é o contrário de pecado, e não de vício. Desse modo, o embate não se dá entre um determinado vício contra uma determinada virtude, mas entre fé e pecado. Aos olhos de Anti-Climacus, a fé cristã é a afirmação tanto do paradoxo como do absurdo e por isso consiste também na possibilidade de escândalo, tema que será retomado na obra Exercício do cristianismo. O escândalo equivale a uma espécie de admiração desgraçada: "A estreiteza do coração, característica do homem natural, é incapaz de submeter-se ao extraordinário que Deus teria destinado para ele. Assim é como se escandaliza" (KIERKEGAARD, 2008, 114). Logo, defender ou apresentar argumentos apologéticos e racionais para o cristianismo parece equivocado segundo sua interpretação: "Pois quem o defende, jamais acreditou nele. Porque se o crê, então o entusiasmo da fé nunca é uma defesa, senão que é um ataque e uma vitória. Um crente é sempre um vencedor" (KIERKEGAARD, 2008, 115).

A definição socrática de pecado é um tema capital abordado na segunda parte da obra e nele se pode perceber claramente a diferença entre a concepção cristã e a concepção pagã. Segundo Sócrates, o pecado equivale à ignorância e aqui vemos claramente a distinção entre o projeto socrático e o projeto cristão. Para o autor de $A$ Doença para a Morte, o problema não visto pelo socrático é exatamente saber de onde se origina a ignorância. Na sua concepção reside exatamente a diferença crucial com o socrático, ou seja, o pecado equivale à consciência: 
Portanto, Sócrates deixa intacto o conceito de pecado e não há dúvida de que isso significa um defeito enorme quando se trata de definir o pecado. Vejamos! Se o pecado é ignorância, então, propriamente não existe..., já que o pecado é cabalmente consciência. Se o pecado, como afirma Sócrates muitas vezes, consiste em que se ignora o que é justo e por isso faz o que é injusto, então o pecado não existe. Porque o pecado não é mais que isso, então há que se supor - e Sócrates certamente que o suporia - que nunca chegará o caso em que um homem cometa uma injustiça consciente do que é justo, ou consciente do que é injusto. É, pois, evidente que se a definição socrática está correta, o pecado não pode, existir em absoluto (KIERKEGAARD, 2008, 117-118).

Logo, na concepção kierkegaardiana, o pecado não pode ser tomado por ignorância como o fazia Sócrates. Disso se pode depreender que o paganismo e o homem natural não conhecem efetivamente o pecado: "Por esta razão, o cristianismo supõe com toda lógica que nem o pagão nem o homem natural sabem o que é o pecado. Sim, o cristianismo está supondo aos berros que é necessária a revelação divina para sabê-lo (KIERKEGAARD, 2008, 118)”. Falta ao paganismo e ao homem natural o tema da vontade, tema claramente cristão, exaustivamente investigado por Agostinho e agora retomado pela perspectiva kierkegaardiana:

Portanto, que categoria falta a Sócrates na sua definição do pecado? A categoria da vontade, do desafio. A intelectualidade grega era demasiado feliz, demasiado ingênua, demasiado estética, demasiado irônica, demasiado engenhosa - em uma palavra, demasiado pecadora em certo sentido - como para que lhe entrasse na cabeça que alguém deixaria de fazer o bem conscientemente, ou consciente do que era justo cometesse uma injustiça. O helenismo estabelece um imperativo categórico intelectual (KIERKEGAARD, 2008, 118).

Curiosamente, a estratégia kierkegaardiana não faz aqui, apesar de pontuar claramente as diferenças entre cristianismo e paganismo, um desprezo do pensador ateniense mas, ao contrário, apresenta entusiasticamente o seu louvor, agindo em concordância com tudo o que sempre pensou o autor de Copenhague, isto é, situando-se sempre estrategicamente entre Sócrates e Cristo: 
Oh Sócrates, Sócrates, Sócrates! Sim, teu nome tem que repetir-se três vezes, e não seria demasiado repeti-lo dez se isso servisse para algo. Opina-se que o mundo necessita uma república, uma nova ordem social e, inclusive, uma nova religião. Mas ninguém pensa que o que o mundo mais tem necessidade, precisamente em virtude de tanto saber que confunde, é de outro Sócrates (KIERKEGAARD, 2008, p.121)

Contudo, falta uma categoria dialética ao socratismo na interpretação kierkegaardiana, a saber, o paradoxo. É certo que a ética da interioridade é, desde as primeiras leituras de Kierkegaard em $O$ Conceito de ironia, elogiada e sua ironia pode ser tomada sempre como ponto de partida, mas nunca como ponto de chegada. Assim temos novamente aqui a afirmação do problema da vontade como um aspecto central e diferenciador da ética socrática (do homem natural e pagão) para a ética do cristianismo:

Portanto, entendendo-o de modo cristão, o pecado radica na vontade, não no conhecimento; e essa corrupção da vontade é algo que excede a consciência do indivíduo. Isto é uma coisa completamente lógica, pois do contrário cada indivíduo deveria estar em condições de poder responder a pergunta de como começou o pecado (KIERKEGAARD, 2008,125).

O irônico da história é que aquilo que se ignora, de fato, é aquilo que é o pecado num dado sentido. Porém, Anti-Climacus parece enfático ao relacionar aqui pecado, consciência e desespero: "Há pecado quando, uma vez mediante uma revelação divina ficou esclarecido que coisa seja o pecado, alguém não quer desesperadamente e diante de Deus ser si mesmo, ou quando, também de maneira desesperada e diante de Deus, quer ser si mesmo" (KIERKEGAARD, 2008, 125).

Ao contrário do que pensou a posição socrática, se cabe dizer aqui que ela pensou algo exatamente similar a isso, o pecado não é uma negação, mas uma posição. Curiosamente, tal tese parece aproximar Kierkegaard de uma interpretação mais ortodoxa no seio do cristianismo e crítica em relação à teologia especulativa. Há, contudo, um aspecto que merece destaque. O autor pseudônimo faz um elogio de uma certa ignorância socrática e, inclusive, a toma como similar a ideia judaica de temor diante da divindade. Assim, "a ignorância 
representada por Sócrates viria a representar uma espécie de temor de Deus ou de culto divino. Neste sentido podemos afirmar que sua ignorância era uma transposição grega da ideia judaica acerca do temor de Deus como princípio da sabedoria" (KIERKEGAARD, 2008, 129).

Se o pecado é uma posição ele também é a possibilidade do escândalo e do choque com o paradoxo, tema que será retomado e mais explorado em $\mathrm{O}$ Exercício do cristianismo. Em outras palavras, o cristianismo estabelece a positividade do pecado e nisso parece se chocar com a razão humana e, no entender de Anti-Climacus, a especulação, que jamais parece ceder lugar ao aspecto paradoxal, tentará explicar o cristianismo ao modo estritamente racional clássico, diminuindo a força do pecado e sua carga de positividade. $O$ contexto do pecado é, sem dúvida alguma, o universo judaico-cristão e parece faltar ao cristianismo atual o pathós primitivo de tal concepção. Desse modo, aos olhos do pensador dinamarquês, os cristãos atuais nem alcançam o pecado, pois não alcançam o tema do espírito e da consciência, isto é, vivem no paganismo e como homens naturais, ou seja, "a cristandade está tão longe de ser o que se chama, posto que a imensa maioria dos homens que nela habitam e a constituem, levam uma vida cristãmente tão pouco espiritual que em definitivo não se pode dizer que seja pecado no estrito sentido cristão da palavra" (KIERKEGAARD, 2008, 135).

Kierkegaard retoma aqui, por meio de Anti-Climacus, algumas teses já expostas em $O$ Conceito de angústia, sob a pena de Vigilius Haufniensis. Contudo, não em relação à angústia propriamente dita, mas como uma tentativa de se aproximar conceitualmente do pecado do ponto de vista cristão até onde isso for possível. Assim é que se afirma aqui - uma vez mais- a tese de atualização do pecado a cada novo pecado e não a perspectiva de compreender cada pecado como uma espécie de somatória ou contabilidade. O critério aqui defendido é que o que não procede da fé é pecado. Com efeito, o pecado é progressão e paradoxo e, nesse sentido, supera a especulação pela fé: "Claro, segundo temos dito, que isto não é objeto da especulação, senão que é algo que se tem que crer, posto que se trata de um paradoxo impossível de compreender humanamente (KIERKEGAARD, 2008, 137). Por isso, o estado de pecado do ser humano é muito mais significativo do que acúmulo de pecados somados ao decorrer de pecados particulares. Afinal, os pecados particulares só servem para reforçar e demonstrar o estado de pecado do ser humano, pois "com cada novo pecado particular se nota de um modo mais sensível a marcha do pecado" (KIERKEGAARD, 2008, 138). Falta ao homem ser espírito e, portanto, alcançar a consciência. O pecado é a oportunidade do homem encontrar-se com seu espírito e sua consciência. 
A ênfase é posta, portanto, no estado de pecado, tema que já tinha sido explorado por Kierkegaard tanto nas Migalhas filosóficas como em O Conceito de angústia. $\mathrm{O}$ pecado reafirmado aqui é intensificação da consciência:

O pecado é desespero; a potenciação constitui o novo pecado de desesperar pelos pecados. Facilmente se vê também que nisso consiste o que se entende por potenciação. Aqui não se trata de um novo pecado como, por exemplo, o de quem roubou cem moedas uma vez e depois, retornando aos seus velhos hábitos, rouba mil. Não, aqui não se trata de pecados isolados; o estado de pecado é o pecado, e este se intensifica numa nova consciência (KIERKEGAARD, 2008, p.141).

Visto desse modo, o desespero pode anteceder a graça e o arrependimento ou pode aprofundar o indivíduo no demoníaco e no desespero do pecado. Assim, a visão de desespero aqui é um pouco diversa daquela explorada por Sartre em $O$ Existencialismo é um humanismo, pois ali o pensador francês parece compreender desespero como imobilismo e não como um aspecto que pode ser importante na busca pela consciência. Aqui se percebe a ocorrência de uma transição da primeira para a segunda parte da Doença para a Morte, isto é, de um eu eterno para um eu consciente e diante de Deus. Querer ser é uma obstinação; não querer ser é uma debilidade. Nesse sentido, a consciência do eu equivale a um aumento da consciência do pecado. Logo, a fusão com Deus se dá no ápice do reconhecimento e consciência do pecado, isto é, no desespero. Outra obra de Sartre que merece aqui destaque numa leitura atenta de $A$ Doença para a Morte seria $O$ Ser e o nada. Jon Stewart observa, com muita clareza, que para o movimento existencialista a noção de consciência e liberdade estão intrinsecamente ligadas.

A teoria da consciência humana é uma das marcas do movimento existencialista francês. Para os existencialistas franceses, a noção de consciência está intimamente ligada ao tema da liberdade. De fato, Sartre diz que para ele os dois termos eram sinônimos. Ao contrário das teorias do inconsciente, Sartre argumenta que há uma 'total translucidez de consciência' e é talvez essa afirmação que melhor caracteriza sua teoria em $O$ Ser e o Nada. (STEWART, 2010,215) 
Curiosamente é preciso notar ainda que o paganismo, segundo a interpretação kierkegaardiana, era mais respeitoso com o nome de Deus do que a cristandade:

No paganismo se pronunciava o nome de Deus com um certo horror, com temor ante o misterioso e, a maioria das vezes, com grande solenidade. Por outro lado, dentro da cristandade não há dúvida de que o nome de Deus é a palavra que mais se usa na linguagem cotidiana e, desde logo, a palavra que menos faz pensar, como se estivesse totalmente vazia de sentido. (KIERKEGAARD, 2008, 150)

Há, portanto, o escândalo do pecado para judeus, gregos e cristãos. O paganismo não pode alcançar a ideia do pecado visto que lhe falta a ideia de Deus. Já a cristandade não alcança a ideia de Deus-Homem (e nem a consciência), pois vive ainda de acordo com as determinações do homem natural e, portanto, no paganismo. Assim, o cristianismo parte do pecado, no entender de Anti-Climacus, nisso se constituiria sua essência e sua diferença cabal para com o projeto pagão: "O cristianismo parte da doutrina do pecado. A categoria do pecado é a categoria da individualidade. O pecado não é nenhum objeto do pensamento especulativo" (KIERKEGAARD, 2008, 153). Afirma-se aqui, portanto, a categoria do indivíduo e da crítica tanto da especulação como da multidão. Assim há aqui tanto o conceito de seriedade do pecado como uma dialética que lhe é própria que necessita de recuperação, pois tal dialética jamais será alcançada pelo pensamento especulativo.

Por meio de tal dialética do pecado, o pseudônimo autor afirma a diferença qualitativa entre Homem e Deus e também reafirma a imagem de Deus como um justo juiz do indivíduo dentro da eternidade. Tal temática será fundamental, por exemplo, na teologia protestante do século XIX, especialmente na obra de Karl Barth, notadamente na sua Carta aos Romanos, importante marco do existencialismo cristão do século $\mathrm{XX}^{6}$. Também a dialética do escândalo não parece menos importante, pois, "o desespero do perdão dos pecados é um escândalo. E o escândalo é a potenciação do pecado" (KIERKEGAARD, 2008, 160). Logo, o escândalo não é um acúmulo de inúmeros pecados particulares, mas a potenciação do próprio pecado. Em outras palavras, o reconhecimento do pecado como um estado e como uma posição, é o que lhe coloca no pólo oposto da perspectiva pagã.

6 Barth, K. A Carta aos Romanos, Sinodal, São Leopoldo, 2016. 
De forma bastante instigante, notamos que não há, ao menos de modo explícito, nenhuma crítica direta feita pelo autor de $A$ Doença para a Morte ao ateísmo ou posição mais crítica da religião no século XIX, tal como aquela exercida por Feuerbach e outros importantes pensadores pós-hegelianos do período. Contudo, aos olhos de Kierkegaard, a recusa do cristianismo como mentira e falsidade é um equívoco. De forma, inclusive irônica, o pensador de Copenhague, a compara como uma espécie de pecado contra o Espírito Santo, isto é, aquele pecado sem perdão. O cristianismo paradoxal tem por obrigação, afirmar a tese do Deus-Homem. Tal tese é verdadeiramente um escândalo. Entretanto, "se se tira o escândalo, o cristianismo não somente se torna paganismo, senão que se faz uma coisa tão fantástica o mesmo paganismo não teria mais remédio que tomá-la por uma brincadeira" (Kierkegaard, 2008, 162). Em outras palavras, o paganismo equivale ao tema do Homem-Deus e o cristianismo ao tema do Deus-Homem. Com efeito, o próprio cristianismo não abole o escândalo (a diferença homem e Deus), isto é, a infinita diferença qualitativa entre homem e Deus. A dialética da fé paradoxal depende, portanto, do escândalo da parte humana e de infinito amor da parte divina, tal como Kierkegaard explora nas Migalhas filosóficas e também nas Obras do amor. Logo, apesar de Anti-Climacus saber bem que uma das facetas do cristianismo também estava na poesia, tal como ele demonstra no Exercício do cristianismo, sua visão é bastante crítica dos intérpretes pós-hegelianos da religião no século XIX que apenas parecem ver o cristianismo apenas como poesia, não sendo capazes de enxergar o seu lado paradoxal: "Esta negação de Cristo enquanto paradoxo comporta, como é óbvio, a negação de todo o cristão: o pecado, o perdão dos pecados, etc, etc" (KIERKEGAARD, 2008, 168) . Ao perder-se num cristianismo que adotou a filosofia pagã, a interioridade proposta pelo cristianismo parece também se embaraçar. Tal pista nos parece de importância capital para entender o que Sartre apontou nos seus textos sobre Kierkegaard e especialmente para formar seu quadro interpretativo da ideia de indivíduo singular.

\section{Conclusão: Qual Kierkegaard Sartre conhecia?}

Hackel, em seu excelente artigo sobre a recepção que Sartre possuía de Kierkegaard $^{7}$, enumera três objetivos a serem perseguidos: 1) Quais traduções

7 Hackel, M. Jean-Paul Sartre: Kierkegaard's influence on his theory of Nothingness in Kierkegaard and Existentialism - Kierkegaard Research: Sources, Reception and Resources-Volume 9. Stewart, Jon (ed.). Burlington: Ashgate, 2011, pp. 323-354. 
de Kierkegaard existiam em francês no período de Sartre?; 2) Dessas traduções, quais efetivamente foram lidas pelo filósofo?; 3) A leitura feita por Sartre também se beneficiou de outros autores que se referiram a Kierkegaard?

As questões não são simples de serem respondidas mas, para enfrentá-las, a autora se vale de numerosa e abundante bibliografia, mostrando claramente as importantes traduções francesas como a de P. H. Tisseau, por exemplo, e elenca ainda importantes estudiosos do pensamento kierkegaardiano na França como, por exemplo, Jean Wahl, dentre outros. Assim, no seu entender, Sartre se depara, já nos tempos de estudante, com um bom número de trabalhos de Kierkegaard sendo traduzidos. Se tais traduções ainda não estão de acordo com os padrões atuais de tradução e se encontram dispersos entre fragmentos religiosos, literários e filosóficos - o que talvez forneça uma ideia pouco unitária da obra- isso também se deve ao momento em que se vive e ao próprio período histórico.

Para responder à segunda questão, isto é, qual dessas obras foi efetivamente lida e apropriada pelo pensador francês, é preciso de mais reflexão ainda. Afinal, numa obra extensa como a de Sartre tal tarefa é complexa e perseguir o Kierkegaard de Sartre é sempre uma empresa difícil. Hackel o faz com maestria a medida em basicamente o limita ao $O$ Ser e o nada e a alguns aspectos muito pontuais em outras obras, coisa que também nós almejamos fazer aqui ao delimitar nosso artigo a citações diretas de Kierkegaard em O Ser e o nada, $O$ Existencialismo é um humanismo e $O$ indivíduo singular.

É igualmente instigante perceber se a leitura de Sartre se beneficiou de outros intérpretes de Kierkegaard. É certo que também se trata de uma questão que merece ser muito aprofundada e, de início, já se aplicaria, inclusive, aos próprios comentadores de Kierkegaard com os quais Sartre teve contato. Além disso, talvez a própria leitura que se fez depois de Sartre sobre Kierkegaard se alterou, ou seja, o próprio Sartre talvez tenha se tornado um ponto importante na interpretação do autor dinamarquês. Por todas essas razões, a autora parece acertar quando diz: "A leitura de Kierkegaard feita por Sartre é tudo, menos simples, não se pode reivindicar que Sartre não deve nada a Kierkegaard. No entanto a dificuldade surge quando se tenta verificar se a imagem de Kierkegaard feita por Sartre ainda se assemelha a Kierkegaard ou se já se tornou demasiado Sartre" (HACKEL, 2011, 346). Dentro desse mesmo espírito, concluímos nosso trabalho, certo de que ele foi apenas um ponto a mais numa discussão que merece ser muito aprofundada. 
ARENDT, H. Compreender - formação, exílio e totalitarismo, Companhia das Letras, São Paulo, 2008.

BEAUFRET, J. Introdução às filosofias da existência, Editora Duas Cidades, São Paulo, 1976.

GLEEN, J. The definition of the self and the Structure of Kierkegaard's Work Nothingness in Kierkegaard International Commentary- Volume 19. Perkins, Robert (ed.). Macon: Mercer University Press, 1987, pp. 05-21.

HACKEL, M. Jean-Paul Sartre: Kierkegaard's influence on his theory of Nothingness in Kierkegaard and Existentialism - Kierkegaard Research: Sources, Reception and Resources- Volume 9. Stewart, Jon (ed.). Burlington: Ashgate, 2011, pp. 323-354.

JOLIVET, R. Sartre ou a teologia do absurdo, Herder, São Paulo, 1968.

LACAN, J. O Seminário - livro 10- A angústia, Jorge Zahar, Rio de Janeiro, 2004.

POLITIS, H. Kierkegaard en France au XXe siècle: Archéologie d'une réception, Éditions Kimé, Paris, 2005.

KIERKEGAARD, S.A. O Conceito de angústia, Editora Vozes, Petrópolis, 2010.

. La enfermedad mortal, Trotta, Madrid, 2008.

. Migalhas filosóficas, Editora Vozes, Petrópolis, 1995.

Pós-Escrito às Migalhas filosóficas volume I, Editora Vozes, Petrópolis, 2013.

REYNOLDS, J. Existencialismo, Editora Vozes, Petrópolis, 2013.

SARTRE, J.P. O existencialismo é um humanismo (Os Pensadores), Abril Cultural, São Paulo, 1987.

. O universal singular in Kierkegaard Vivo.
Vários autores (ed.). Madrid: Alianza, 1980, pp. 17-49. O Ser e o nada, Editora Vozes, Petrópolis, 2011.

STEWART, J. Idealism and Existentialism- Hegel and Nineteenth and Twentieth-Century European Philosophy, Continuum, London, 2010. . Søren Kierkegaard - subjetividade, ironia e crise da modernidade, Editora Vozes, Petrópolis, 2017.

THEUNISSEN, M. Kierkegaard's Concept of Despair, Princeton University Press, New Jersey, 2005. 